\title{
Editorial
}

\section{The Jubilee of the Czechoslovak Red Cross}

\author{
Jan Kyselák \\ Tomas Bata University in Zlín, Faculty of Logistics and Crisis Management, Department of Population Protection, Uherské Hradiště, Czech Republic
}

This year marks the passing of more than one century since the Czechoslovak Red Cross (CSRC) was established as a predecessor of the current $C$ zech Red Cross (CRC). The proposal for establishing the CSRC was submitted in February 1919 by the daughter of our president at that time - Alice Garrigue Masaryk (1879 Vienna - 1966, Chicago, USA). Besides other things, she found the role of such an organization to be in the training of hospital attendants and in the operation of various social facilities. Such a proposal was quite logical when you consider the horrors of WW1, the disintegration of the Austro-Hungarian Empire and the formation of an independent Czechoslovak Republic (which until 29th February 1920 went by the name of Republic Czechoslovak). President Tomáš Garrigue Masaryk (1850 Hodonin - 1937 Lany) soon gave consent to the establishment of this organization, and he authorized Alice Masaryk - who had good work experience from medical and social areas - to build the CSRC organization. He also appointed her as its chairwoman. The CSRC Articles of Association were approved in the same year and the CSRC was also recognized as an auxiliary organization of the Military Medical Service. In December 1919 the International Red Cross Committee recognized the CSRC as another national organization of the Red Cross - and in January 1920 it was accepted into the League of Red Cross Societies. Alice Masaryk was the chairwoman of this organization for two decades. She contributed to its overall development and, thanks to her efforts, the first high school for social workers was established in the Czechoslovak Republic in 1919. Social workers training for nursing field care, and later also those training to work in nursing and medical services in families were educated at that school.

It has to be mentioned that the CSRC also had its predecessors: the Patriotic Society for Aid in the Czech Kingdom and the Patriotic Society for Aid in Moravia were already established as independent organizations in the second half of the 19th century. After the Austrian Red Cross Society was established, the two above-mentioned societies became parts of it with their names slightly amended. These societies were focused on training medical and nursing personnel, charity, and the preparation of medical services during war, etc. It is also worth mentioning that the first nursing school on the territory of the then Austria was established in Prague in 1874 (including the adoption of the nursing care code) and in Vienna in 1882 . As part of the above-mentioned societies, the so-called 'Patriotic Female Societies for Aid', were also known as they provided reserve hospitals with nurses. The Red Cross activities intensified during WWI, when the aid was delivered to injured soldiers by a large number of voluntary nurses. The newly established CSRC then not only took over property from the above-mentioned societies, but also the operation of medical and social facilities and nursing schools in Prague and Brno.

After WWI, a crucial role of the CSRC was to help the war victims (returning legionaries, search and rescue, etc.). Later, the organization established medical advisory centers for adults and children. The visiting nurses, whose role was to work directly in families - especially those families suffering from tuberculosis - contributed significantly to the area of prevention and home nursing care. The home care included help provided to the patients with their personal hygiene, bed adjustment, re-bandaging, medicine delivery, etc.

The CSRC established several medical facilities, e.g. 'Ch. G. Masaryk Children's Specialized Sanatorium' in Bukovany, which is still in operation. This organization has also dealt with the training of both professional and voluntary medics and nurses, as well as with the promoting of nursing care to the public. As well as this it has organized and provided aid abroad. The CSRC also contributed to the building of the national network of the CSRC Car Rescue Service (the predecessor of the current Emergency Medical Service) and the development of the network of family-type orphanages, etc.

After the occupation, the CSRC was dissolved in August 1940. The exiled government in London immediately decided upon its re-establishment, so in September 1940 the contemporary exile CSRC was established again. The activity of this organization commenced in the Czechoslovak Republic (Protectorate of Bohemia and Moravia at that time) at the end of WWII in April 1945. Its staff participated in treating those affected by the typhus epidemic in the Small Fortress in Terezin, building the first-aid stations and treating the wounded during the Prague uprising, and organizing the transport of medics in Prague.

After WWII, it had the primary and not easy task of restoring the CSRC activities on the basis of the pre-war Articles of Association - and also of organizing help to the victims of war. The CSRC Higher Nursing Schools in Prague and Kosice were newly established in 1946.

\footnotetext{
* Author for correspondence: Jan Kyselák, Tomas Bata University in Zlín, Faculty of Logistics and Crisis Management, Department of Population Protection, Studentské nám. 1532, 68601 Uherské Hradiště, Czech Republic; e-mail: kyselak@utb.cz http://doi.org/10.32725/kont.2019.054
} 
The organization went through a rather difficult period after February 1948. Between 1948 and 1989, based on the political course of events in the Czechoslovak Republic, new Articles of Association were approved several times - regulating its activity and also changing its organizational structure. In 1951, the CSRC became a voluntary organization according to Law No. 68/1951 Coll. on Voluntary Organizations and Assemblies. Its property and established services were taken over by the state (including nursing and medical services in families, which were again provided as late as after 1990). Moreover, in 1958 the CSRC became a part of the National Front, which enabled interventions into its activities. Nevertheless, in the period from the 1950s to the 1980s the CSRC tried to adopt an image according to the traditions, values and goals set during the First Czechoslovak Republic. At the beginning of the 1950s, First Aid Stations were being established with the aim of providing treatment and first aid prior to the doctor's arrival. The CSRC voluntary nurses and Civil Defense Medical Crew were gradually prepared to deal with potential emergency events. It is well known that the medical staff of this organization provided aid during various sport and social events, including All-Sokol Gatherings (Spartakiades).

The transformation of the CSRC into the CRC began in 1993, when the Czech and Slovak Federative Republics split, by adopting the new Articles of Association at the Conference of the CRC in June 1993. These Articles changed the organization of the CRC according to the First Republic arrangement. At present, the CRC society is made up of more than 60 registered regional societies, almost 500 local teams, 13,500 members and about 2,500 registered volunteers. The permanent First Aid Stations provided first aid to almost 700 people in 2018, whilst temporary stations treated almost 1,000. In 2018, almost 10,000 people were given medical treatment during sporting, cultural and other events under CRC medical supervision. Care was provided to almost 7,000 clients in the area of social services through the CRC professional home nursing care agency (Alice). Nursing and other care was also provided to almost 70 clients of the CRC House of Care, among others. More detailed information on the current activities of the $C R C$ is available on the website of this organization and in periodically published annual reports.

Scope of authority of the CSRC was supported not only by the Articles of Association, but also by the passed laws, namely Act No 479/1921 Coll. On the Protection of the Emblem and the Name of the Red Cross; Act No 60/1952 Coll. On the Czechoslovak Red Cross and on the Use of the Red Cross Emblem, Badge and Name; and the still valid Act No 126/1992 Coll. On the Protection of the Red Cross Emblem and Name and on the Czechoslovak Red Cross. The CRC acts as a recognized auxiliary organization to the Military Health Service in compliance with Act No 126/1992 Coll. It also specializes in the area of population protection and provides aid during disasters and other emergency situations. It provides health, rescue, social and other humanitarian services both at home and abroad. It encourages citizens to take an active part in fulfilling medical tasks. Its departments closely cooperate with medical service providers. One of the tasks of the CRC is also to disseminate awareness of international humanitarian law. The CRC is the recognized Red Cross society and an integral part of the worldwide International Red Cross and Red Crescent Movement.

The role, organization and scope of authority of the CSRC (today the $\mathrm{CRC}$ ) has experienced continuous development since its origin. Activities of this significant non-governmental, non-profit humanitarian organization operating throughout the whole of the Czech Republic were and will always be aimed at the areas related to the provision of medical, social and humanitarian aid. In its one-hundred-year history, this organization has managed to succeed with honor in the most difficult of situations. It has contributed not only to the origin and development of many medical, social and educational institutions, but also to the education and practical training of thousands of professionals and volunteers - who, among other things, have significantly contributed with their nursing care to the mitigation of suffering of the affected people both at home and abroad. The organization surely deserves our great acknowledgment - as do all of its former and current members for their devotion.

It is possible to get further acquainted with the full history of the origin and development of the CSRC (the CRC) in a very interesting publication called A century with the Red Cross: 100 years of the Czechoslovak and Czech Red Cross (Jukl and Majrichová, 2019).

\section{References}

1. Act No 479/1921 Coll., on the protection of the emblem and the name of the Red Cross. In: Sbírka zákonů České republiky, částka 127/1921.

2. Act No. 68/1951 Coll., on Voluntary Organizations and Assemblies. In: Sbírka zákonů České republiky, částka 34/1951.

3. Act No 60/1952 Coll., on the Czechoslovak Red Cross and on the use of the Red Cross emblem, Badge and Name. In: Sbírka zákonů České republiky, částka 34/1952.

4. Act No 126/1992 Coll., on the protection of the Red Cross emblem and name and on the Czechoslovak Red Cross. In: Sbírka zákonů České republiky, částka 30/1992.

5. Jukl M, Majrichová J (2019). Století s Červeným křižem: 100 let Československého a Českého červeného kříže. Praha: Český červený kříz. 